\title{
Missóes e devoções no "Nordeste" do Brasil: a atuação eclesiástica e a formação de uma taumaturgia em torno do Frei Damiáo de Bozzano (1930-1940)
}

Carlos André Silva de Moura*

Aerton Alexander de Carvalho Silva ${ }^{* *}$

\section{RESUMO}

Neste artigo, analisamos o projeto missionário do frade capuchinho Frei Damião de Bozzano, especialmente durante a sua atuação em parte do "Nordeste" do Brasil nas décadas de 1930 e 1940. Através das propostas da História Cultural, traçamos um perfil missionário do eclesiástico, a partir do seu ingresso na Ordem Capuchinha, com destaque para os seus estudos, funçôes religiosas, a imigração para o Brasil e a construção de uma devoção, constituindo-se como imprescindíveis para a compreensão dos projetos católicos e as suas relaçôes com as questôes históricas, políticas e sociais do início do século XX. Para isso, foram utilizados documentos confessionais e pessoais, periódicos, memórias e publicaçôes do religioso, com o objetivo de compreender a estruturação das atividades da sua ordem no país, especialmente a construção das representações de santidade entre os fiéis.

Palavras-chave: missóes católicas; Ordem dos Capuchinhos; Frei Damião de Bozzano; devoçóes eclesiásticas; taumaturgia.

\section{Missions and devotions in the "Northeast" of Brazil: ecclesiastical action and the formation of a thaumaturgy around Friar Damiáo de Bozzano (1930-1940)}

\section{ABSTRACT}

This article analyzes the missionary activity of the Capuchin friar Damião de Bozzano, focusing on his stay in part of the "Northeast" of Brazil in the 1930s and 1940s. Through

DOI: http://dx.doi.org/10.1590/2237-101X02204706

Artigo recebido em 12 de junho de 2020 e aceito para publicaçáo em 28 de outubro de 2020.

* Professor da Universidade de Pernambuco, Departamento de História, Recife/PE - Brasil. E-mail: carlos. andre@upe.br. ORCID: https://orcid.org/0000-0002-5584-1398.

** Professor do Centro Universitário Facol, Arquidiocese de Olinda e Recife, Instituto de Filosofia e Teologia, Recife/PE - Brasil. E-mail: aertonaacarvalho@gmail.com. ORCID: https://orcid.org/0000-0002-5799$972 X$. 


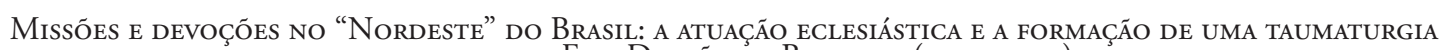
em torno do Frei Damiấo de Bozzano (I930-1940)

Carlos André Silva de Moura e Aerton Alexander de Carvalho Silva

the lens of Cultural History, we trace the profile of the friar from his entry into the Capuchin Order. We emphasize his studies, religious duties, immigration to Brazil, and the building of his devotion, all of which are essential for understanding Catholic projects and their relations with historical, political, and social issues in the early 20th century. This article is based on confessional and personal documents, periodicals, memoirs and religious publications, and it aims to understand the organization of his order's activities in the country, especially the construction of representations of holiness among believers.

Keywords: catholic missions; Capuchin Order; Friar Damião de Bozzano; ecclesiastical devotions; thaumaturgy.

\section{Misiones y devociones en el "Noreste" de Brasil: la actuación eclesiástica y la formación de una taumaturgia en torno del Fray Damiáo de Bozzano (1930-1940)}

En este artículo analizamos el proyecto misionario del Fraile capuchino Fray Damiáo de Bozzano, especialmente durante su actuación en parte del "Noreste" de Brasil en las décadas 1930 y 1940. A través de las propuestas de la Historia Cultural, trazamos un perfil misionario del eclesiástico, a partir de su ingreso en la Orden Capuchina, con destaque para sus estudios, funciones religiosas, la migración para Brasil y la construcción de una devoción, constituyéndose como imprescindibles para la comprensión de los proyectos católicos y sus relaciones con las cuestiones históricas, políticas y sociales de inicios del siglo XX. Para eso, fueron utilizados documentos confesionales y personales, periódicos, memorias y publicaciones de lo religioso, con el objetivo de comprender la estructuración de las actividades de su Orden en el país, especialmente, la construcción de las representaciones de santidad entre los fieles.

Palabras clave: misiones católicas; Orden de los Capuchinos, Frey Damiäo de Bozzano; devociones eclesiásticas; taumaturgia.

Si ele se fixar num logar qualquer, nova Mecca surgirá ainda nos sertóes, apezar do poder destruidor com que o progresso technico dos nossos dias vem solapando certos modos de vida.

Octacilio Nobrega de Queiroz

As análises sobre as missōes e os seus personagens, religiosos ou grupos organizados, envolvem vários processos que estão conectados com as questôes políticas, sociais, culturais, 


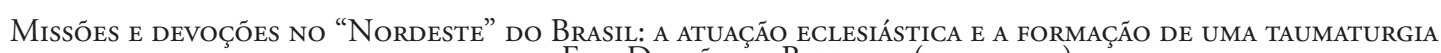
em torno do Frei Damiấo de Bozzano (I930-1940)

Carlos André Silva de Moura e Aerton Alexander de Carvalho Silva

econômicas e religiosas em distintas temporalidades. Os projetos em torno das atividades para a expansáo dos modos de crer devem ser compreendidos de forma ampla, a partir de estruturas internacionais e multiculturais, para que assim possamos visualizar a expansão das ações realizadas por diferentes práticas eclesiásticas.

No entanto, parte dos projetos missionários ainda estáo silenciados pela historiografia. Mesmo assim, notamos que os estudos sobre as ordens católicas no período moderno, ou os grupos protestantes durante a segunda metade do século XIX no Brasil, têm avançado nos centros acadêmicos, mas ainda sem uma análise aprofundada sobre as suas atuaçóes nos "sertôes" ou no Brasil Central1. Para isso, são analisados os (des)encontros entre os grupos populacionais, a formação de novas devoções, as invençóes religiosas, as representaçôes culturais entre as crenças, as negociações entre os líderes eclesiásticos e a formação de um grupo de fiéis comprometidos com as práticas eclesiásticas (MONTERO, 2006; POMPA, 2003).

As missóes precisam ser compreendidas como uma trajetória sistemática, complexa, de longa duração, transnacional, com imprevistos e que possibilitam a elaboração de redes sociais fundamentais para se repensar as ortodoxias. Tais questóes possibilitam a elaboraçáo de novas formas de devoção, com o reconhecimento do pluralismo e das práticas cotidianas nos espaços de atuação. No entanto, é preciso destacar que nem sempre os encontros aconteciam de modo harmônico ou sem conflitos. As missóes contribuíram com o surgimento de novas propostas teológicas, adaptações com outras prioridades, conflitos, estratégias de açóes e formas de compreender as hierarquias de sentido (MOURA et al., 2017, p. 15).

A partir da compreensão da pluralidade das práticas, táticas e representações das missões religiosas, analisamos parte da atuação de Frei Damião de Bozzano (1898-1997), eclesiástico italiano da Ordem dos Frades Menores Capuchinhos, que, radicado no Brasil, desenvolveu um extenso projeto no interior da regiáo Norte ${ }^{2}$. Para isso, utilizamo-nos de documentos eclesiásticos e pessoais, periódicos e depoimentos, com o objetivo de compreender as narrativas construídas sobre o religioso, suas aproximaçóes com questôes políticas, culturais e sociais. Compreender a cultura missionária dos capuchinhos também foi importante para as nossas reflexôes, uma vez que as missóes populares foram consideradas um instrumento de grande importância pastoral para os projetos da Igreja Católica dos séculos XIX e XX (BEOZZO et al., 1985, p. 209-210).

\footnotetext{
${ }^{1}$ Referências ao interior do Brasil, presentes em diferentes narrativas de missionários e viajantes da primeira metade do século XX (Cf. SILVA, 2016).

${ }^{2}$ Compreendemos que o termo Nordeste é uma construção conceitual dos anos de 1940, com questóes relacionadas à cultura, à sociedade e à economia do período. Por esse motivo, em alguns instantes utilizaremos os termos "Norte do país" ou Nordeste, acompanhando a periodização das referências documentais (Cf. ALBUQUERQUE JUNIOR, 1999).
} 


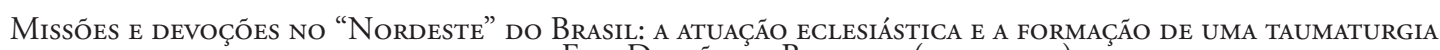
em torno do Frei Damiấo de Bozzano (I930-1940)

Carlos André Silva de Moura e Aerton Alexander de Carvalho Silva

Nesse sentido, o objetivo do artigo foi compreender o trabalho missionário de um eclesiástico e a construção de novas representaçôes para as devoçôes católicas nas décadas de 1930 e 1940. Para isso, analisamos os seus projetos, formas de adaptação das ortodoxias no espaço de atuação, as relaçôes com uma ordem social e as leituras construídas pelos fiéis em torno do religioso italiano. Sendo assim, foram importantes as propostas da História Cultural das Religiôes, uma vez que tivemos a necessidade de nos debruçar sobre as narrativas históricas e as representaçôes sobre o catolicismo do período investigado. Com as propostas culturais, conseguimos compreender como os eventos foram elaborados, interpretados e lidos em uma temporalidade específica (CHARTIER, 1990; 2002).

\section{A construção do perfil eclesiástico do Frei Damião de Bozzano}

Nas primeiras décadas do século XX a Itália atravessava profundas mudanças político-sociais, resultado do processo de unificação dos seus territórios, dos debates sobre a secularização, as consequências da Primeira Guerra Mundial (1914-1918) e da ascensão política de Benito Mussolini (1883-1945). No mesmo período, também era percebida a lenta industrialização e modernização da economia, com diferenças entre a região Sul, agrícola e pobre, e a Norte modernizada, questóes que dificultavam a integração nacional (FROHLICH, 1987, p. 159).

Com o acompanhamento das mudanças no cenário político e econômico, parte das açôes dos representantes da Igreja Católica na Itália perdeu a credibilidade. Nesse sentido, em 1870 o Concílio Vaticano I (1869-1870) tornou-se uma alternativa para o soerguimento do catolicismo, com a construção de alternativas para os trabalhos eclesiásticos das diferentes organizaçôes. Uma das representaçôes construídas sobre o período era que os católicos pareciam estacionados em um meio confessional, sem compreender a burocracia e a centralização estruturada pela Igreja. A questão proporcionou a formação de um clero disciplinado, mas distante dos debates modernos, com a organização de um sistema fechado, mas com a pretensão de ter o monopólio das interpretações sobre o mundo (KUNG, 2002, p. 203).

O início do século XX foi marcado pelo "ressurgimento" de parte das açôes da Igreja, especialmente após o movimento concordatário e o fim da Questão Romana ${ }^{3}$. Nesse período, diferentes ordens reestruturaram as suas atividades missionárias, como os Beneditinos, Dominicanos e Capuchinhos. Entre as congregações femininas, as Irmãs Clarissas, Beneditinas, Carmelitas e Ursulinas também recuperaram parte dos seus projetos e membros (AUBERT, 1981, p. 481; ATKIN; TALLETT, 2003, p. 110-111).

\footnotetext{
${ }^{3}$ Evento referente à disputa territorial entre o governo italiano e os papas, entre 1861 e 1929, que foi concluído com a criação do Vaticano em 1929.
} 


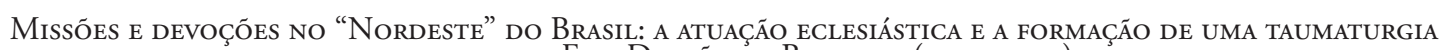
em torno do Frei Damiấo de Bozzano (I930-1940)

Carlos André Silva de Moura e Aerton Alexander de Carvalho Silva

É no contexto das transformaçôes sociais e da Igreja que situamos o início da formação eclesiástica do Frei Damiáo. Nascido em 5 de novembro de 1898, na cidade de Bozzano, recebeu o nome civil de Pio Giannotti. Aos 12 anos ingressou no Seminário Seráfico de Camigliano, lugar onde desenvolveu os seus estudos regulares. Em maio de 1914, aos 16 anos, no Convento de Vila Basílica, na Toscana, ingressou no noviciado da Ordem Capuchinha.

Terminada a formação canônica inicial após um ano, emitiu os votos de obediência, pobreza, castidade e recebeu o nome de Frei Damião de Bozzano. O nome fazia referência à igreja onde se encontrava o crucifixo que, supostamente, São Francisco de Assis (1181 ou 1182-1226) teria dialogado e que o despertou para a missáo. Segundo os escritos franciscanos, acredita-se que o momento foi marcado por uma conversa que destacou: "Francisco, não vês que a minha casa está em ruínas? Vai, pois, e a restaura para mim. [...] Com muita boa vontade o farei, Senhor" (CELANO, 2018).

Pouco se sabe sobre os sete anos da vida do frei como estudante. As informaçóes estão resumidas ao Convento de Lucca, onde iniciou os seus estudos filosóficos durante a Primeira Guerra Mundial. Devido ao conflito bélico, aos 19 anos foi convocado para o Serviço Militar, com atuação no acampamento em Zara, zona disputada com a Iugoslávia, por mais de três anos após a guerra.

Sobre a sua participação no combate, parte da historiografia devocional destaca que o Frei Damião "mostrou-se sempre um soldado desajeitado, pois não havia nascido para matar, mas para uma missão mais nobre: pregar a Palavra de Cristo" (MOURA, 1978, p. 35). Desde as primeiras referências das suas atuaçôes, as informações demonstram a relação com a vida eclesiástica e o distanciamento de outras atividades laborais, como o serviço militar. Em carta ao Frei Jorge de Massa, o frade apresentou as impressóes sobre o período no campo de batalha, com informação de que se alistou em:

[...] setembro de 1917 no depósito do regimento 26 em Piacenza; - congelado em outubro de 1920 pelo Comando Militar e Distrito de Zadar (Dalmácia) - Servi na infantaria;-de Cotolengo (Piacenza) estava na frente em 25 de novembro de 1917; - Monte Grappa (pico Azolone) foi o lugar de onde fui assistido por ter os pés congelados; depois da minha convalescença, que passei em Alessandria (Piemonte) no Depósito de 37, fui novamente enviado ao fronte, mais ou menos em julho de 1918, ainda no Grappa, e permaneci até o armistício; Passei um pouco mais de tempo em Basaldella (Udine); e fui enviado para a Dalmácia - Zara; Zara velha. Sibenik (casa do escritor italiano Tomasec) e em Zara recebi a Licença, parti mais ou menos em 20 de outubro, pertencendo naquele tempo à brigada 240 que tem o depósito em Bari. Giannotti Pio (LAZZARI, 2003, p. 21) ${ }^{4}$.

\footnotetext{
${ }^{4}$ Tradução nossa. No original: “[...] setembro del 1917 presso il deposito del reggimento 26 in Piacenza; -
} 


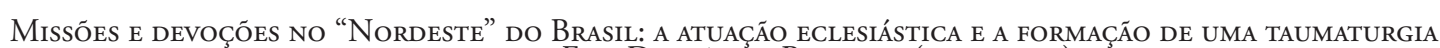
em torno do Frei Damiấo de Bozzano (I930-1940)

Carlos André Silva de Moura e Aerton Alexander de Carvalho Silva

Nota-se que, além dos perigos de servir ao exército em um momento de guerra, Frei Damiăo também enfrentou problemas de saúde relacionados ao congelamento dos pés. A sua experiência no conflito tornou-se bastante emblemática, acompanhando-o por toda a vida, como a fobia que apresentava em relação aos fogos de artifício que os fiéis soltavam durante as missóes no Brasil. A carta demonstrou a movimentação territorial de um jovem militar em diferentes espaços, mesmo sem a formaçâo específica, uma vez que os ensinamentos do frade estavam direcionados à vida eclesiástica.

A documentação demonstra que as representaçóes de um eclesiástico atento à vida devocional foram construídas desde os primeiros relatos sobre o personagem. A atuação do frade em uma Europa em guerra foi fundamental para as suas decisóes sobre as missóes, impulsionada pelas decisôes em torno do Concílio Plenário Latino-Americano, que ofereceu um impulso para a Igreja em diferentes países (Cf. MOURA, 2020, p. 66).

Com o fim do período de serviços militares, o frade retornou aos seus estudos. Em 1921 realizou os votos perpétuos e iniciou a formação em Roma, onde habilitou-se com a titulação em filosofia, direito canônico e teologia dogmática, atestado pela Universidade Gregoriana. Após esse período, retornou ao Convento de Vila Basílica, com a função de vice-mestre e professor dos noviços. Em 1928 assumiu o cargo de diretor dos estudantes da Província de Lucca, com a divisão do tempo com o ensino de Teologia no Seminário Episcopal de Massa.

O período de formação, ordenação, estudos e atuação junto aos noviços foi fundamental para a construção das concepçôes teológicas do Frei Damião. O momento teceu o religioso que desembarcou em terras brasileiras, migrante do campo para a cidade, com aspectos nacionalistas, do catolicismo tridentino, fiel à Igreja romana, avesso à modernidade e defensor de uma ordem eclesiástica e dos "bons costumes". As suas críticas às discussóes políticas e sociais estavam baseadas nas propostas de documentos papais, como o Syllabus Errorum, publicado por Pio IX (1792-1878) em 1864, que destacou os "erros" da sociedade moderna (PIO IX, 1864).

Em 18 de dezembro de 1930, o Definitório Geral da Ordem Capuchinha redistribuiu as missóes italianas no Brasil. Desta forma, os estados de Pernambuco, Alagoas, Paraíba e Rio Grande do Norte passaram para a responsabilidade da Província de Lucca. Com as mudanças estruturais, o Frei Félix de Olívola desembarcou na cidade do Recife para tomar posse no Convento da Penha, designando um grupo de frades Luqueses para as missóes na regiáo,

congelato in Otobre del 1920 dal Comando e Distetto militare di Zara (Dalmazia) - Ho servito infanteria; - di Cotolengo (Piacenza) fui al fronte il 25 di Novembre del 1917; - il monte Grappa (picco Azolone) fu il mio posto donde me ausentei por congelamento di piedi; dopo la convalescenza, che passai in Alessandria (Piemonte) nel Deposito del 37, fui inviato novamente al foronte, più o meno nel giuglio di 1918, sempre nel Grappa, ond e rimasi fino all'armistizio; passai ancora un poco di tempo in Basaldella (Udine); e fui inviato in Dalmazia - Zara; Zara vecchia. Sebenico (patria dello scrittore italiani Tomasec) e in Zara riccevi il Congedo, appartevi più o meno in Ottobre del 20, appartenendo in quel tempo alla brigatta 240, che ha il deposito in Bari. Giannotti Pio". 


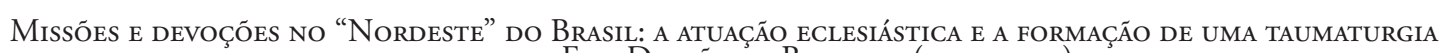
em torno do Frei Damiấo de Bozzano (I930-I940)

Carlos André Silva de Moura e Aerton Alexander de Carvalho Silva

dentre os quais estava o Frei Damiáo de Bozzano, que embarcou no porto de Gênova, para uma viagem com destino ao Brasil. ${ }^{5}$

No dia 28 de maio de 1931 o frade chegou ao porto do Recife, depois de passar pelo estado da Guanabara, atual Rio de Janeiro. Com o eclesiástico desembarcaram os freis Ignácio de Carrara e Bento de Terrinca ${ }^{6}$. No período a paisagem urbana do Recife já se configurava pelos ares cosmopolitas, com prédios clássicos, ruas largas e a Basílica da Penha da Ordem Capuchinha como um dos principais monumentos no bairro de São José.

Os três primeiros meses do Frei Damião no Brasil foram de estudos, aproximação com a língua portuguesa e atividades desenvolvidas na vida conventual. Aos poucos o religioso iniciou pregaçóes, decorando alguns termos, pois não dominava o idioma, o que levava as pessoas a dizer que ele pregava melhor que falava (MOURA, 1978, p. 36). Em relação às estratégias utilizadas por religiosos estrangeiros para o desenvolvimento das suas atividades, Eduardo Hoornaert afirmou que "era costume, entre os pregadores populares, anotar e decorar textos já traduzidos do italiano pelos próprios capuchinhos" (HOORNAERT, 1997, p. 116). A afirmativa demonstra a circulação de religiosos de diferentes nacionalidades, como parte de um projeto de reformas eclesiásticas, com a colaboração das missóes, responsáveis por parte da reconfiguraçáo católica na América Latina.

Nos primeiros anos de atuação o frade desenvolveu diversas atividades de orientação nos espaços eclesiásticos da cidade. As açôes também serviram para o aprendizado do português, a sua formação enquanto pregador e a construção da representação como "missionário do povo". Em diferentes periódicos da década de 1930 é possível encontrar informaçôes sobre as atividades do capuchinho, como a cooperação com a Diretoria das Senhoras de Caridade, que avisou a suas associadas "[...] que o retiro anual começara amanhă, às 1 horas, no Colégio da Estância, havendo, durante os três dias, conferências às 9, 14 e 16 horas, pelo revmo. Capuchinho frei Damião, pregador do retiro"?

\footnotetext{
${ }^{5}$ Desde a chegada dos primeiros capuchinos ao Brasil, os projetos eram coordenados por eclesiásticos oriundos das províncias da Itália. Em Pernambuco já existiam religiosos da região de Lucca, mesmo antes da atuação dos membros da ordem a partir de 1930 (ZAGONEL, 2001).

${ }^{6}$ Anos depois o Frei Ignácio de Carrara retornou para a Itália por motivos de saúde. Durante a Segunda Guerra Mundial, no dia 15 de setembro de 1944, após sua missa em Forte Dei Marmi, na região da Toscana, província de Lucca, o local foi atacado pelos nazistas, pois os religiosos alertaram os jovens sobre o assédio dos soldados alemães. Frei Bento de Terrinca morou no Convento da Penha do Recife e em 1934 fundou, juntamente com Frei Félix de Olívola, o Convento dos Capuchinhos de Maceió. Em agosto de 1939 o jornal A Ordem registrou a sua presença no Convento dos Capuchinhos de Natal/RN. O eclesiástico faleceu aos 33 anos no dia 16 de novembro 1940.

${ }^{7}$ DIRETORIA das Senhoras de Caridade. Diario de Pernambuco, Recife, 22 jul. 1933. p. 4.
} 


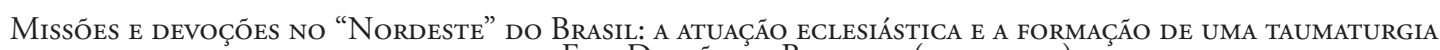
em torno do Frei Damiấo de Bozzano (I930-1940)

Carlos André Silva de Moura e Aerton Alexander de Carvalho Silva

Em setembro de 1931 o Frei Damião, em conjunto com outros membros da Ordem dos Capuchinhos, iniciou as missóes em diferentes localidades do país. As atividades começaram pela cidade de Gravatá, em Pernambuco, desdobrando-se em uma intensa ação missionária que o levou a percorrer diferentes espaços do Nordeste. De acordo com Jociel Gomes, para Frei Damião o convento "era o lugar do descanso depois da labuta missionária, ali ele repousava, refazia suas forças, reencontrava os frades e novamente partia para outras paragens, de acordo com sua agenda sempre lotada" (GOMES, 2013, p. 45).

É possível notar a construção da representação da imagem do missionário em torno do Frei Damião. As narrativas estavam destinadas à formação da ideia de um religioso que caminhava junto ao povo, debatia questóes cotidianas e combatia pontos sensíveis para os ensinamentos da Igreja Católica nas primeiras décadas do século XX, a exemplo do casamento, do protestantismo e do pensamento de esquerda. Em reportagem do Diario de Pernambuco, Gomes Maranhão apresentou as suas impressôes sobre uma das missóes do religioso na cidade de Souza, interior da Paraíba. Segundo o jornalista, a cidade:

[...] andou em reboliço a semana passada. Mas um reboliço dos bons e que só fez bem ao sertão. Dom Matta, bispo da diocese de Cajazeiras, a que pertence aquella cidade, botou na cabeça visitar a velha parochia do velho conego Vienna e houve um festáo desse tamanho. Frei Damiáo chegou na frente, uns dois dias antes, para preparar o pessoal. Tambem desceu foi gente de todos os pés da serra pra vêr o bispo e ouvir a palavra do frade, que, dizem, é meio santo. [...] A festa durou quase a semana inteira. Foi gente se chrismar, não foi gettoni. Casamento tôrto que Dom Matta e frei Damião endireitaram nem se conta o número. Por sua vez, fosse a custa de juramento, o olho de Moscou tinha cegado dessa feita. Triste de quem aparecesse ali naquele momento com história molle de comunismo, de dividir as terras ou tomar a mulher do outro. ${ }^{8}$

Nota-se que, mesmo estando há pouco tempo no Brasil, as realizaçôes do Frei Damião, especialmente a construção de uma identidade com o povo e a efetivaçáo de um catolicismo tridentino', contribuíram com a elaboração de uma representação de santidade em torno do eclesiástico. As suas ações foram fundamentais para os projetos do clero, como as atividades que defendiam a formação de uma neocristandade, o fortalecimento das práticas católicas nas açôes cotidianas e a construção de discursos que condenavam açôes que estavam em desacordo com as propostas da Cúria romana (MOURA, 2018). Em certa medida, os sermôes se alinharam às propostas de líderes civis no combate ao comunismo, a partir de uma visão da moral católica.

\footnotetext{
${ }^{8}$ MARANHÃO, Gomes. O Sertão velho melhora de sorte. Resultado dumas santas missóes em Souza, na Parahyba. Diario de Pernambuco, Recife, 25 out. 1936. p. 14.

${ }^{9}$ Modelo baseado nas propostas do Concílio de Trento, realizado entre os anos de 1545 e 1563, com ideias que defendiam a unidade da fé e a disciplina eclesiástica em torno da Cúria romana.
} 


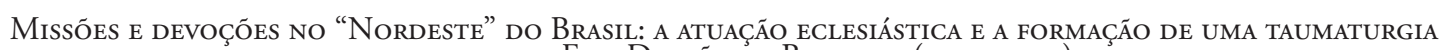
em torno do Frei Damiấo de Bozzano (I930-1940)

Carlos André Silva de Moura e Aerton Alexander de Carvalho Silva

O trabalho eclesiástico do religioso também esteve direcionado a um plano político e cultural conservador de silenciamento às ideias de esquerda. Tais propostas encontraram respaldo em um espaço social de manutenção das estruturas patriarcais, contrárias às ideias democráticas que circulavam no país. Nesse sentido, o posicionamento político-religioso do Frei contribuiu para a reafirmação dos poderes locais e o afastamento dos discursos não "autorizados" pelos representantes dos espaços visitados.

A partir dos relatos da reportagem, também se nota que o frade já possuía a fama de santidade, o que colaborava para arregimentar fiéis de diferentes localidades para as atividades da Igreja Católica. O momento era utilizado para a confirmação dos ritos de passagem estipulados pelo catolicismo, como crismas ou casamento, açôes que também buscavam combater o que era classificado como a desordem social e política.

$\mathrm{Na}$ obra intitulada Em defesa da fé, o frade demonstrou a sua proposta de catolicismo, com um tratado de crítica ao protestantismo, com comparaçóes entre o que classificou como os "erros da religião herética" e as "virtudes" católicas. As suas ideias se fundamentaram na tradição bíblica, nos ensinamentos da Igreja romana, na defesa dos sacramentos e na importância da confissão. Para o frei, a verdadeira religião estava fundamentada em "I - Que Jesus Cristo fundou a sua Igreja e entregou seu governo a Pedro; II - Que foi vontade de Jesus que Pedro transmitisse o governo da Igreja a seus sucessores; III - Que os sucessores de Pedro são os Papas" (BOZZANO, 1955, p. 13).

A partir de argumentaçôes que reafirmavam a centralidade da Igreja romana, o capuchinho defendeu a ideia de reconstrução nacional baseada na proposta católica. Nesse instante, parte dos fiéis o legitimou como porta-voz das suas necessidades, classificando-o como santo e destruidor de um progresso que era identificado como inimigo da religião. Com o objetivo de expandir as suas ações, as missóes do Frei Damião se tornaram atividades institucionais na região, constituindo-se como representante de novas formas de demonstrar o crer.

Pelas estradas dos Sertôes: itinerários do missionário capuchinho nas décadas de 1930 e 1940

Além das atividades nos estados de Alagoas, Paraíba, Pernambuco e Rio Grande do Norte, espaço da Custódia Provincial Capuchinha no Nordeste $^{10}$, Frei Damião também realizou incursóes no Amazonas, onde desenvolveu trabalhos entre os indígenas, Bahia, Ceará, Sergipe, São Paulo e Piauí. No entanto, a sua vida eclesiástica foi marcada pela atuação no

\footnotetext{
${ }^{10}$ Inicialmente a Província Capuchinha do Nordeste foi denominada de Missão Religiosa, substituída por Custódia Provincial Capuchinha no Nordeste, respeitando as necessidades de apresentar um número mínimo de religiosos e projetos para a instituição. A Custódia é uma parte da Ordem em que os frades gradualmente desenvolvem a presença em uma região. A Província possui uma consistência própria que lhe permite desenvolver atividades com utilidade da vida da Ordem (CONSTITUIÇÓES, 2014, p. 117).
} 


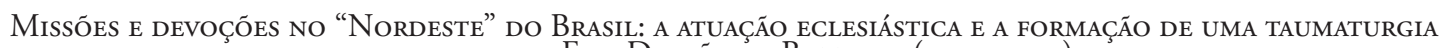
EM torno do Frei Damiấo de Bozzano (I930-I940)

Carlos André Silva de Moura e Aerton Alexander de Carvalho Silva

Nordeste do Brasil, lugar em que apresentou diferentes projetos com os integrantes da Ordem dos Frades Menores Capuchinhos.

No mapa abaixo é possível visualizar o deslocamento do frade entre os anos de $1931 \mathrm{e}$ 1949, com açôes em diferentes Arquidioceses e Dioceses. No período, os aspectos sociais, antropológicos, econômicos, culturais e geográficos foram fatores relevantes para afirmação das identidades religiosas da população. Nesse sentido, são expressivas as relaçóes dos fiéis com as açôes missionárias do Frei Damiáo de Bozzano, com a elaboração de atividades voltadas para os projetos da Igreja Católica no início do século XX.

Figura 1: Mapa das Missōes Pregadas por Frei Damiāo de Bozzano da Custodia Provincial de Pernambuco no Brasil (1931-1949)

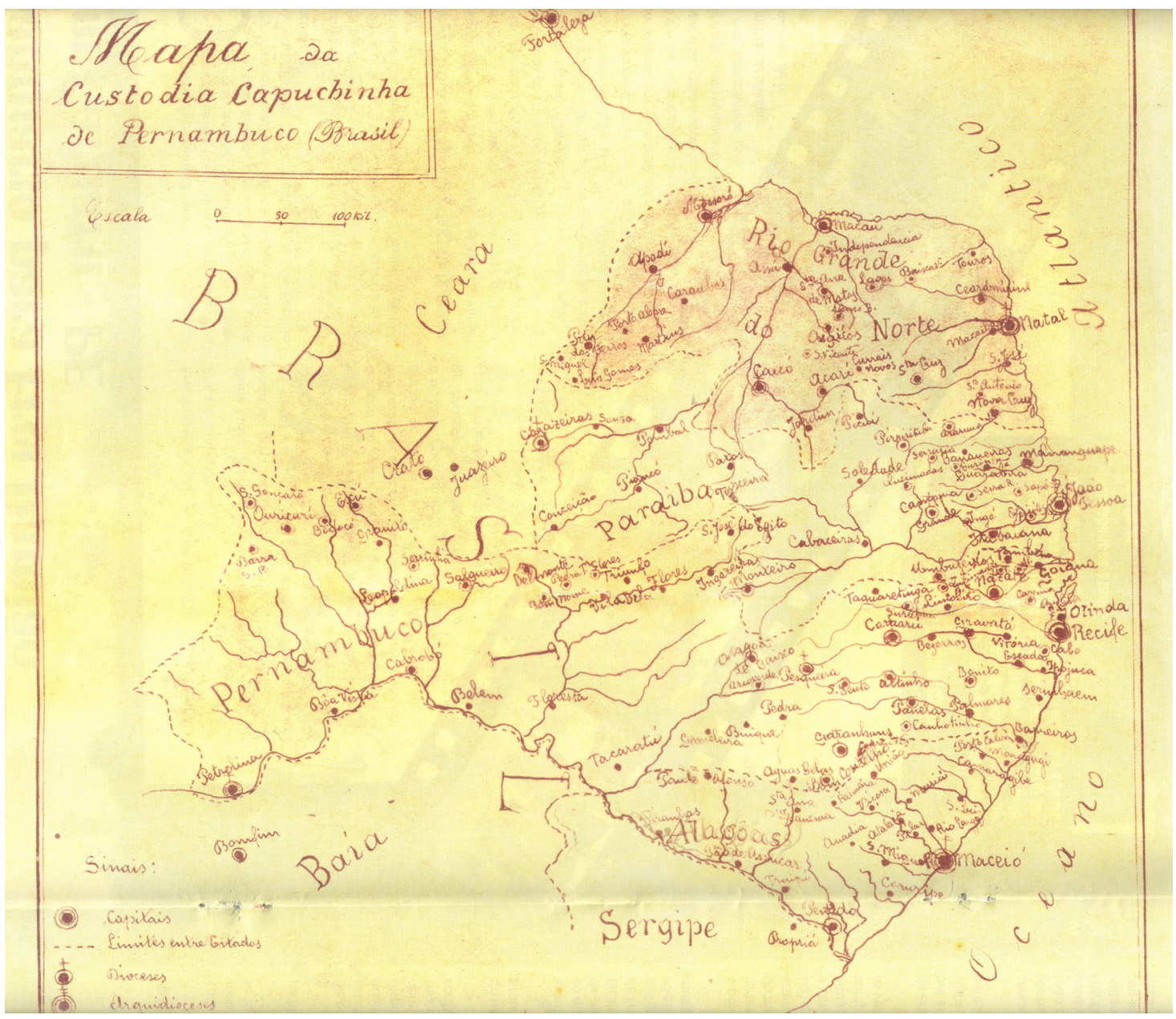

Fonte: Frei Otávio de Terrinca. Arquivo dos Capuchinhos da Província Nossa Senhora da Penha do Nordeste do Brasil

Na maioria das vezes, a programação diária das "santas missóes" era dividida em etapas: por volta das 5 ou 6 horas da manhã era realizada uma missa. Após este momento, em um 


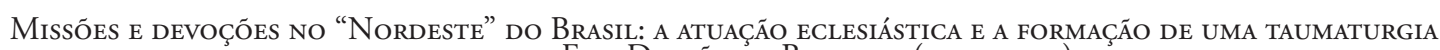
em torno do Frei Damiấo de Bozzano (I930-1940)

Carlos André Silva de Moura e Aerton Alexander de Carvalho Silva

púlpito na praça, largo ou estação de trem da cidade, o missionário realizava a explicação catequética, iniciando pela existência de Deus e concluindo com o juízo universal. A programação seguia com o catecismo das crianças, com o método que envolvia perguntas e a concessão de prêmios para as melhores respostas. Ao fim do processo, era realizado um exame público para a primeira comunhão. No horário da tarde se realizava a explicação doutrinária, com base nos textos do evangelho. No período entre os turnos, os religiosos mobilizavam os fiéis para os trabalhos de benfeitorias, como a manutenção das capelas e cemitérios, construção de açudes e aberturas de estradas. O dia terminava com uma missa e/ou procissão, ao som de hinos e cânticos, mas também das madeiras, pedras e tijolos dos trabalhos ainda em conclusão (BEOZZO, 2008, p. 209-210).

Nas regiōes distantes dos centros urbanos, como as identificadas no mapa, as atividades desenvolvidas nos dias das missóes tornavam a chegada dos religiosos o maior evento do ano, com momentos de "catarse coletiva". Com os missionários, a exemplo dos capuchinhos, aprendiam-se as percepçôes morais do catolicismo e se reafirmava o prestígio do clero, especialmente em um espaço em que as atividades institucionais eram ausentes (SERBIN, 2006, p. 70). Em regiōes distantes das Dioceses, a população passava meses sem visitas pastorais, o que era agravado pela falta de transporte e a pequena quantidade de religiosos para atender os fiéis de localidades extensas.

Segundo Erika Helgen, os eventos também podem ser considerados como um projeto de combate ao crescimento do protestantismo nas regióes interioranas do Nordeste. Como estratégia para este objetivo, os projetos dos capuchinhos se tornaram populares devido à identificação com o cotidiano no ambiente rural, com as chamadas "pessoas simples", e à construção de identidades com religiosos específicos (HELGEN, 2020, p. 169-171).

Além das narrativas elaboradas sobre as missóes do Frei Damião, os fiéis dessas localidades também construíam representaçóes sobre outros personagens importantes para a compreensão das questôes sociais e religiosas, como Virgulino Ferreira da Silva - Lampião (1898-1938) e o Padre Cícero Romáo (1844-1934), respectivamente. Durante as pesquisas, não identificamos registros do encontro entre o religioso capuchinho e os outros dois atores históricos. No entanto, não foram poucas as reportagens que buscaram conectar os três nomes que movimentaram o imaginário popular. Em reportagem que refletia sobre a ideia de santidade em torno do frade, notamos a aproximação entre as suas atividades com a do Pe. Cícero Romão. Na matéria, o jornalista destacou que:

Sabia da fama de frei Damião, mas não julgava que chegasse a tanto. Ouvia dizer que nesses sertóes afóra, ele era a maior espinha de garganta dos inimigos da Igreja Catholica. [...] Um povão medonho, ido não sei de quantas léguas da Parahyba, Pernambuco, Rio Grande do Norte e Ceará, enchia todas as suas ruas. [...] Adeante me informaram que era o pessoal de 


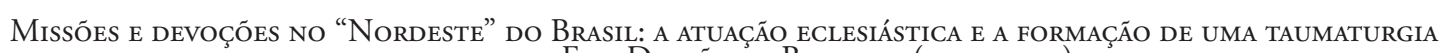
em torno do Frei Damiấo de Bozzano (I930-1940)

Carlos André Silva de Moura e Aerton Alexander de Carvalho Silva

frei Damião. [...] O fradezinho era nem mais nem menos do que o dono da vontade de todos aquelles sertanejos que caminharam, a pé, léguas e mais léguas [...] coisa nunca vista nesse Nordeste brabo, de tão bonita que foi. O poder de frei Damião para aquella gente é absoluto. Elle vira e revira a vontade do sertanejo de alpercata. E nesse sentido o sertão começa a se encher de lendas, factos alusivos á pessoa, ao prestigio do humilde missionário, que passa uma noite inteira, das 6 ás 6 , confessando o pessoal. A chronica que vae assim se formando toma os mais variados aspectos. Ali mesmo em Cajazeiras, naquelles dias, li folhetos de trovas populares que diziam ser frei Damiáo um enviado do padre Cicero de Joazeiro para preservar o sertão das proezas de satanaz. ${ }^{11}$

As missóes executadas no final dos anos de 1930 já estavam marcadas pelas grandes multidôes, procissóes e devoçóes em torno do frei. Mesmo assim, a construção das suas representaçóes ainda estava ligada a devoçóes mais consolidadas, como ao padre Cícero, que na reportagem foi apresentado como o responsável pela vinda do frade ao Brasil. No entanto, é importante destacar que a formação da imagem do "santo missionário" foi elaborada de modo independente, a partir das suas atividades, da forma de pregação e da construção dos cultos nos espaços que ocupou. A movimentação da população, que caminhava quilômetros para acompanhar o frade, em busca de milagres ou graças, reforçou as identidades com os missionários e os atritos com os integrantes de outras denominaçóes.

Os registros das açóes missionárias dos capuchinhos contribuíram para que pudéssemos elaborar um itinerário dos lugares missionados pelo frei ${ }^{12}$. As memórias das primeiras missóes do frade, na cidade pernambucana de Gravatá entre os dias 22 e 25 de setembro de 1931, enfatizam que na ocasião o religioso passou "três dias ininterruptos confessando fiéis na capela, em Riacho do Mel, distante quatro quilômetros da sede do município" (OLIVEIRA, 1997, p. 38). No mês seguinte a documentação relatou uma missão em Quipapá e, entre os dias 22 de outubro e 3 de novembro, outra em São Benedito. Pela aproximação das datas, compreende-se que quando uma atividade era concluída, outra iniciava imediatamente, fato que contribuiu para que no primeiro ano o frade contabilizasse quatro missóes em 18 dias de açôes ininterruptas.

Durante o ano de 1932 o Frei Damião realizou 12 missóes nas cidades de Bebedouro, (atual município de Agrestina), Bezerros, Caruaru, Sairé, Itabaiana, Brejo da Madre de Deus, Belo Jardim, Sanharó, Genipapo, Correntes, Panelas, Escada, Amaragi e Alto Bonito. No final desse período o religioso escreveu aos seus pais, relatando sua dedicação à pregação, o seu estado de saúde e como era acolhido pelo povo. No documento foi destacado que:

\footnotetext{
${ }^{11}$ FREI Damiáo pregando no morro do Redemptor em Cajazeiras. Diario de Pernambuco, Recife, 23 jul. 1939. p. 16.

${ }^{12}$ A narrativa foi construída a partir dos documentos conservados nos arquivos das províncias capuchinhas do Nordeste do Brasil e em Lucca, na Itália.
} 


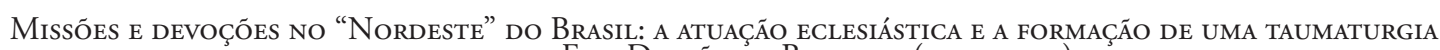
EM TORno do Frei Damiấo de Bozzano (I930-I940)

Carlos André Silva de Moura e Aerton Alexander de Carvalho Silva

Queridos pais,

Eu deixei para escrever a vocês nas festas de Natal porque nestes últimos meses eu passei muito tempo fora do convento para pregar e foi um pouco ruim para escrever. Por outro lado, vocês já sabem que eu sou muito preguiçoso para escrever e, portanto, não se preocupem. Estou muito bem. Guglielmo disse que soube [...] que eu estive doente por dois dias. Não era para dizer-lhe estas coisas! Mas já o Pe. Felice lhes escreveu isto, eu lhes digo que a minha doença foi a mesma indisposição estomacal que tive em Bozzano quando fui pregar durante a visita do bispo. Coisas que não podem ser chamadas absolutamente de doença. Guglielmo está pedindo livros: é melhor que não faça isso para não faltar às minhas regras. Reze por mim. Cumprimente-me Pedro e sua família e todos os parentes. Seu querido filho Frei Damião. Recife 20-12-1932. Amanhã parto para pregar novamente. Se vissem que acolhimento fazem a mim! Na Itália um bispo não é acolhido com tanta festa. ${ }^{13}$

Mesmo com os problemas de saúde relatados nas correspondências enviadas à família, as atividades missionárias não reduziram, com avanço em diferentes cidades e com estratégias que colaboravam para o aumento das devoçóes nas localidades visitadas. As problemáticas relatadas na carta contrastam com o mapa apresentado anteriormente, quando notamos o registro de diferentes localidades onde o missionário esteve em menos de duas décadas. É importante destacar que a saúde fragilizada também fez parte da construção do imaginário popular em torno do frade, com a construção de narrativas que a classificava como provaçôes para o eclesiástico.

No quadro a seguir é possível visualizar a atuação do frei em cada ano, com atividades nos vários estados da Província dos Capuchinhos e em outras circunscrições. É importante destacar que os números das missões não resumem a quantidade de atividades desenvolvidas pelo italiano, mas indicam os deslocamentos em cada ano. É fundamental lembrar que mesmo quando permanecia no Recife, mantinha-se atuante em diferentes obras da Igreja Católica.

${ }^{13}$ LUCCA. Arquivo da Província dos Frades Capuchinhos. Cópia Pública III, 711. Tradução nossa. No original: "Carissimi genitori, Ho lasciato di scrivervi per le feste del Natale perché in questi ultimi mesi sono stato molto tempo fuori di convento a predicare e mi tornava un poco male scrivere. Del resto voialtri già lo sapete de vecchio che sono molto pigro a scrivere e perciò non istarete in pensiero. Sto molto bene. Guglielmo dice che seppe dalla [...] che io ero stato malato due giorni. Nenche a dirle queste cose! Ma giacché il P. Felice scrisso anche questo, vi dirò che fu la mia malattia fu quella medesima indisposizione di stomaco che ebbi a Bozzano, quando venni a predicare per la visita del vescovo. Cose queste che non si possano chiamare assolutamente malattia. Mi dice ancora Guglielmo che domandi libri: é meglio peró che non lo faccia per non mancare alle mie regole. Pregate per me. Salutatemi tanto Pietro e sua famiglia e tutti i parenti. Vostro affmo. Figlio Fr. Damião. Recife 20-12-32. Domani l'altro parto novamente. Se vedeste che accoglienze farmo! In Italia un vescovo non è accolto con più festa". 


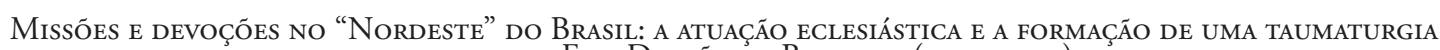
em torno do Frei Damiấo de Bozzano (I930-1940)

Carlos André Silva de Moura e Aerton Alexander de Carvalho Silva

Tabela 1: Distribuição das missóes do Frei Damião de Bozzano entre 1931 e 1939

\begin{tabular}{|c|c|c|c|c|c|c|c|c|c|}
\hline Ano & $\mathbf{1 9 3 1}$ & $\mathbf{1 9 3 2}$ & $\mathbf{1 9 3 3}$ & $\mathbf{1 9 3 4}$ & $\mathbf{1 9 3 5}$ & $\mathbf{1 9 3 6}$ & $\mathbf{1 9 3 7}$ & $\mathbf{1 9 3 8}$ & $\mathbf{1 9 3 9}$ \\
\hline Número de Missóes & 04 & 12 & 15 & 30 & 21 & 19 & 35 & 31 & 24 \\
\hline
\end{tabular}

Fonte: Livros dos Arquivos das Províncias Capuchinhas do Nordeste do Brasil e em Lucca na Itália

Da cidade de Patos, interior da Paraíba, em 27 de outubro de 1936, o frade enviou uma carta aos seus pais, com relatos sobre o seu estado de saúde, as atividades desenvolvidas nas missóes, a reação dos fiéis e informaçóes sobre os deslocamentos territoriais na província religiosa. O eclesiástico destacou que estava "[...] muito saudável. Escrevo pouco, porque estou ocupado dia e noite. As pessoas andam 50 e $60 \mathrm{~km}$ a pé para vir me ouvir. Hoje termino minhas missões no estado da Parahyba e amanhã vou a Macau perto de Natal [...]"14. A partir da documentação apresentada, nota-se a surpresa e consciência do religioso em relaçáo ao esforço da população para acompanhá-lo, especialmente no que se refere aos deslocamentos entre as cidades.

$\mathrm{Na}$ imagem a seguir é possível visualizar um registro em uma das missóes do Frei Damião. Além dos fiéis, possivelmente oriundos de diferentes localidades, nota-se a presença de representantes políticos e personalidades que buscavam legitimar as suas açôes a partir da construção da ideia de aproximação com o eclesiástico. Deve-se lembrar que em diferentes espaços, os discursos católicos foram fundamentais para a validade das açóes civis, especialmente em lugares com forte devoção religiosa. As crianças também se faziam presentes nesse momento, levadas pelos pais que, em muitas ocasiôes, esperavam a benção ou graças em torno de problemáticas ligadas à saúde.

Com as vestimentas de frade capuchinho, que também trazia legitimidade às suas açôes, em meio à população, em área aberta, com braços em formato de acolhimento e que ao mesmo tempo simbolizava a cruz e o martírio de Cristo, o religioso era acolhido em cada região por onde passava. Com a sucessão das atividades, as devoçôes dos fiéis e as representaçôes construídas pela imprensa, católicos e outros religiosos, o período das missóes era compartilhado entre os compromissos públicos e açôes da Igreja.

${ }^{14}$ LUCCA. Arquivo da Província dos Frades Capuchinhos. Cópia Pública III, 713. Tradução nossa. No original: "Carissimi Genitori, Sto molto bene di salute. Scrivo poco, perché sono occupato giorno e notte. Il popolo cammina a piedi 50 e $60 \mathrm{~km}$. per venire a udirmi. Oggi termino le mie missioni nello stato di Parahyba e domani vado a Macau vicino a Natal. Pregate per me; io pure vi ricordo sempre al Signore. Tanti saluti alla famiglia de Pietro. Affmo. Frei Damião. Patos 27-10-36. P.S.: Ritorno in Convento dopo Pasqua”. 


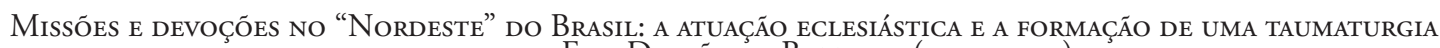
em torno do Frei Damiấo de Bozzano (I930-I940)

Carlos André Silva de Moura e Aerton Alexander de Carvalho Silva

Figura 2: Missões do Frei Damião em Cajazeira (PB) em 17 de setembro de 1936

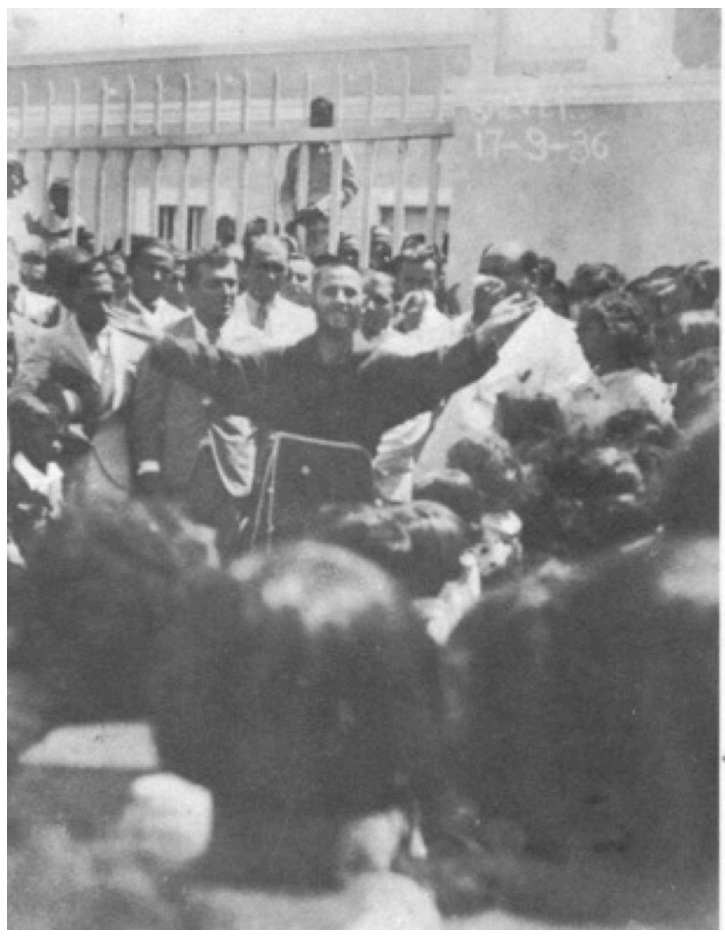

Fonte: Arquivo pessoal do Frei Jociel Gomes

As narrativas presentes na documentação pessoal do frade demonstram a compreensão que tinha sobre a sua importância para os fiéis, a estruturação e o fortalecimento do catolicismo na regiáo e os trabalhos desenvolvidos em vários espaços. Em cartas para a sua família, informou sobre o crescimento das missóes e o reconhecimento dos esforços que os romeiros realizavam para se deslocar até os lugares de pregação ou a organização de acampamentos para acompanhar as missóes.

Em correspondência do dia 4 de março de 1940 o eclesiástico relatou as pregaçóes e a devoção dos peregrinos junto a suas atividades. Frei Damião informou que estava:

Pregando continuamente, quase me esqueci de lhe desejar boas festas. Estou nesta cidade, a $300 \mathrm{~km}$ de Natal. Há milhares e milhares de pessoas participando da pregação: muitos já percorreram quilômetros para vir. Para contar uma, outro dia apareceu uma mulher de 80 anos, que caminhou $60 \mathrm{~km}$ para confessar-se, o que sempre acontece com muita frequência. Reze por mim. Cumprimente Pietro, Beppa e os netos. Muitas saudações a Guilherme quando ele chegar em casa. Seu filho. Frei Damião. ${ }^{15}$

${ }^{15}$ LUCCA. Arquivo da Provincia dos Frades Capuchinhos. Cópia Pública III, 715. Tradução nossa. No original: "[...] Predicando continuamente, quasi mi dimenticavo di augurarvi le buone feste. Mi trovo in questa città, distante un $300 \mathrm{~km}$ di Natal. Sono migliaia e migliaia di persone che assistono alla predicazione: molte hanno fatto parecchi kilometri per venire. Per contarvene una, l'altro giorno si presentò una vecchia di 80 


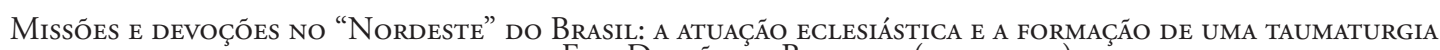
em torno do Frei Damiấo de Bozzano (I930-1940)

Carlos André Silva de Moura e Aerton Alexander de Carvalho Silva

O deslocamento de uma fiel por $80 \mathrm{~km}$, com o objetivo de se confessar com o frade, demonstrava a importância do eclesiástico entre os católicos. No entanto, o fato também pode confirmar a falta da atuaçáo cotidiana do clero em diferentes localidades, que era suprida pelos eventos proporcionados pelas "santas missōes". Mesmo com as duas interpretaçôes, deve-se compreender que a chegada dos missionários, especialmente quando acompanhados por Frei Damiāo de Bozzano, movimentava os devotos de diferentes regiōes (HELGEN, 2020, p. 171).

As atividades do Frei Damiáo em uma cidade demandavam estrutura para o recebimento dos fiéis. Com as missóes nas localidades, era preciso estabelecer espaços para as missas, lugar para o confessionário, instalaçôes para os fiéis dormirem, alimentarem-se e descansarem das longas distâncias percorridas. Mesmo que as primeiras missóes tenham sido organizadas de modo espontâneo, com a formação das representaçôes de santidade em torno do frade italiano, as formas de se pensar os eventos precisaram acompanhar as demandas dos devotos, da Ordem dos Capuchinhos e da Igreja Católica nos ambientes visitados.

No entanto, é preciso compreender que o formato das atividades iniciais do frade não significou falta de planejamento. As primeiras décadas do século XX foram marcadas pela atuação dos diferentes grupos masculinos e femininos, com projetos de expansão das práticas católicas, sacralização do político, proposição de estruturas educacionais e colaboração com as atividades internacionais de recatolização pensadas pela Cúria Romana (MOURA, 2019). A organização das missóes, custódia e província dos capuchinhos no Nordeste do Brasil demonstram o planejamento em torno dos projetos eclesiásticos na localidade, não sendo possível ser compreendida sem a ordenação necessária.

A revista Dom Vital, editada pelos frades capuchinhos, apresentou um perfil das açôes missionárias do religioso italiano. Onze anos após a sua chegada ao Brasil, conseguimos visualizar a importância atribuída às missôes na região onde desenvolveu o seu trabalho. O periódico classificou o religioso como um:

Apóstolo de grande estilo, frei Damião é um homem de uma só e única ideia: a da evangelização. Apesar de sua saúde aparentemente precária, há longos anos que sem interrupção, ativa-se na ação pacificadora do apostolado missionário, ganhando para a fé e a unidade católica os vastos campos da catequese com palavra ardente, zelo inflamado, exemplo de virtudes que o distinguem e que merecidamente lhes lucram o prestígio que goza as mais largas simpatias tanto nas cidades como nos povoados. O seu nome corre de boca a boca, exercendo um verdadeiro fascínio sobre todos que tiveram a felicidade de conhecê-lo de perto. As multidóes

anni che fece a piedi $60 \mathrm{~km}$ per confessarsi con me cose queste accadono molto frequentemente. Pregate per me. Salutatemi Pietro, Beppa e i nipoti. Molti saluti a Guglielmo quando capitarà a casa. Vostro figlio. Frei Damião. Sta. Rita 9-12-50". 
Missóes e devoçóes no "Nordeste" do Brasil: a ATUaÇão eclesiástica e a formação de uma taumaturgia em torno do Frei Damiấ de Bozzano (I930-1940)

Carlos André Silva de Moura e Aerton Alexander de Carvalho Silva

afluem compactas e pressurosas a sua passagem, desejosas de vê-lo, de ouvir-lhe a palavra perpassada de amor seráfico, a palavra da fé, da uniáo, da paz. ${ }^{16}$

Alguns dos pontos que sempre estavam presentes nas representaçóes sobre o Frei Damião eram relacionados à sua saúde, à capacidade de resistência durantes as missóes, à adesão dos fiéis e ao seu poder de agregar devotos em torno das atividades desempenhadas. Do mesmo modo, as narrativas apresentavam o modelo de catolicismo proporcionado nos espaços que visitava, com um discurso de defesa dos valores religiosos e a estruturação de uma ordem eclesiástica. A capacidade de evangelização o distinguia de outros frades, constituindo-se em exemplo para os ingressantes na vida religiosa, com a elaboração de um modelo de devoçáo em que os fiéis eram visitados por um representante carismático, que se conectava com as linguagens dos "Sertóes".

A crença no "poder da benção" conferida pelo religioso era refletida em suas açôes cotidianas durante as missôes. Além das missas, confissôes ou romarias, o frei desenvolveu uma extensa obra assistencial para a população de diferentes localidades. Entre as realizaçôes estavam açóes em escolas, a perfuração de poços artesianos, a construção de capelas, atendimentos de profissionais de saúde destinados aos idosos, manutenção de plantaçôes e projetos de irrigação para a melhoria da renda (AGUIAR; SILVA, 2015, p. 452).

A mística construída em torno do religioso também estava direcionada a uma taumaturgia presente em seus gestos, roupas, partes do corpo ou açôes. Entre as narrativas sobre o frei, existiam crenças sobre a efetivação de graças alcançadas, milagres e que o religioso flutuava para se deslocar por diferentes localidades. Ao eclesiástico também era atribuída a representação de conselheiro, orientador pessoal e "agente de cura" (OOSTERHOUT, 2010, p. 30).

No início dos anos de 1940, parte da imprensa apresentou algumas das notas sobre o Frei Damião, que foram reforçadas em várias matérias. O Diario de Pernambuco destacou que o frade:

[...] impressiona pelas barbas proféticas, o seu corpo franzino, mortificado pelos jejuns e onde a tuberculose lhe destruiu um dos pulmões. A sua vida é um estar em fórma inalterável para a religiáo de Deus. Nem as vicissitudes de uma existencia erradia, as viagens ásperas e demoradas, a bôa ou má alimentaçáo, o labor intenso pela religiáo, nada disso abate aquelle corpo fragílimo de santo do agiologio franciscano. [...] Á sua chegada reacende-se a fé. As igrejas se enchem, o povo resa contrictamente, os confissionarios trabalham noite e dia, os amancedos se cesam. Ninguem quer ficar má com Deus. Chegou o frade prodigioso, capaz de livrar de todos os pecados o que diz é algo mais do que a verdade. É a própria salvação, o

\footnotetext{
${ }^{16}$ REVISTA mensal dos PP. Capuchinhos da Penha e da Causa de D. Vital. Recife: Escola Gráfica Editora, ano VI, set./out., 1942.
} 


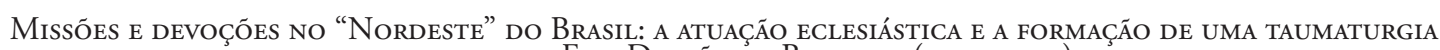
em torno do Frei Damiấo de Bozzano (I930-1940)

Carlos André Silva de Moura e Aerton Alexander de Carvalho Silva

caminho indicado, áspero e cruciante, á morada do eterno. [...] Já em Patos, a matutada dos arredores quiz arrancar os fios de sua barba por acredital-a capaz de milagres [...] Ao chegar em Ceará-Mirim, o juiz embirrou com Frei Damiāo por causa do casamento civil. [...] Já em Matta Limpa, quase o deixaram nú os fieis na ânsia de obter pedaços da sua sotaina milagrosa. [...] Por outras localidades onde passou, dizem as pessoas crédulas que o frade não se alimentava quase-nada e que se tornava invisível. [...] A aureola da santidade se aproxima do pallido missionário italiano. ${ }^{17}$

As vestimentas, o uso da barba longa, a estatura pequena, as informaçóes sobre as doenças e as dificuldades para se alimentar atribuíam ao capuchinho um compromisso com práticas ascéticas e de santidade. As suas açóes, o estado de saúde e as caraterísticas corporais também eram utilizadas para o igualar ao povo, com a formação de uma devoção em torno do seu modelo de propagar a fé.

Algumas de suas açóes tinham o objetivo de combater a legislação em torno do processo de secularização e laicização, instalado a partir da implementação da República no Brasil, como a exigência do casamento religioso para que os fiéis pudessem continuar em uma vida devocional. Em outra frente, as ações do eclesiástico foram sensíveis nos atritos da Igreja Católica com as práticas dos protestantes e espíritas, com a classificação destas correntes como heréticas. Muitas são as notícias das querelas entre o frei e representantes das igrejas evangélicas, reforçando as disputas religiosas nas primeiras décadas do século. Na mesma fonte, destacou-se que no Crato "[...] quase havia muita bala entre catholicos e protestantes por causa do capuchinho. Em Cajazeiras [...] houve uma encrenca terrível com delegado, os protestantes e o missionário. [...] Em Macahyba, um pastor nova-seita desistiu de uma discussão com o valente frade travada perante imenso público". ${ }^{18}$

As críticas a outras práticas religiosas, ou os "desvios" da população, apresentavam-se como parte do modelo de catolicismo compartilhado com os fiéis. A sua obra estava fundamentada em estruturar as "[...] apóstrofes aos pecadores, amancebados, adúlteros, protestantes, espíritas, acenando-lhes com voz vibrante a consequência inevitável de suas vidas transviadas: O inferno" (BOZZANO, 1955, p. 4). De tal modo, o religioso também era compreendido como um "[...] destinado a opor um dique intransponível à onda avassaladora da corrução com que a heresia do Lutero ameaça as mais esplêndidas tradiçóes do Brasil católico" (BOZZANO, 1955, p. 4).

Tais ações também eram refletidas na formação de novos eclesiásticos. Não sem interesse, parte dos manuais de teologia que eram usados nos seminários ainda sustentavam a ideia da união entre a Igreja e o Estado, onde o poder civil era responsável pelo controle dos cor-

\footnotetext{
${ }^{17}$ QUEIROZ, Octacilio Nobrega de. Reaviva-se o mysticismo das populaçôes do interior do nordeste. Diario de Pernambuco, Recife, 17 jan. 1941. p. 9.

${ }^{18}$ Idem.
} 


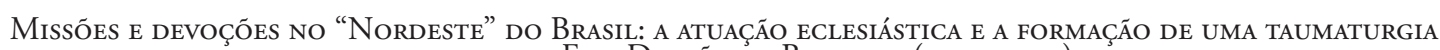
em torno do Frei Damiấo de Bozzano (I930-1940)

Carlos André Silva de Moura e Aerton Alexander de Carvalho Silva

pos, enquanto a Igreja Católica orientava o espírito. Nesse sentido, membros do episcopado aceitavam o regime de apoio mútuo e a colaboração entre as autoridades civis e eclesiásticas. Nessa lógica de cooperação, ações do clero, a exemplo das realizadas durante as missôes, reforçaram discursos de autoridades governamentais, com a demonstração do caráter sacral de alguns detentores do poder em regiōes interioranas (AZZI, 2008, p. 198).

\section{Considerações finais}

Durante os 66 anos de vida missionária, entre 1931 e 1997, Frei Damiáo foi protagonista ao menos em quatro intensos momentos na política do Brasil: a Era Vargas (1930-1945), o período entre as ditaduras (1945-1964), o regime civil-militar (1964-1985) e a Nova República, iniciada com a redemocratização. Durante as suas açôes, manteve-se alinhado a posicionamentos tradicionais da Igreja Católica, com respeito às autoridades e sem atritos com os representantes políticos associados ao seu pensamento. A sua colaboração com governantes se baseava na ideia de que "[...] toda sociedade exige um chefe que a dirija [...], tanto é verdade isto, que, quando num país não há mais quem mande, temos a desordem, a revolução, a morte" (BOZZANO, 1955, p. 18).

Para parte do clero da primeira metade século XX, a imagem do Frei Damiáo era uma figura modelar de líder católico, que unia a ideia de pátria e Igreja, com a rejeição ao nacionalismo de conteúdo liberal ou socialista. Hospedado em casas de indivíduos influentes nas cidades por onde realizava as missóes, de algum modo o religioso chancelava projetos civis a partir do seu carisma e da sacralização da vida política, corroborando, endossando ou induzindo à manutençẫo de açôes coronelistas e assistencialistas que perduram até hoje. Um exemplo desta prática foi o lançamento da campanha de Luiz Cristovão dos Santos, candidato a Deputado Estadual por Pernambuco, que enfatizou que seria vitorioso "[...] com oito a dez mil votos. Quem patrocina a candidatura é frei Damiáo, o novo padre Cicero do sertão $[\ldots . .]^{\prime 19}$

Tais propostas estavam presentes em seus discursos, com a defesa do conservadorismo na sociedade, a manutenção das bases tridentinas e convicçôes cívico-religiosas. Em pronunciamento na Assembleia Legislativa de Pernambuco em 1977, o eclesiástico destacou que:

[...] para o vosso bem, para o bem de vossas famílias, para a prosperidade da pátria, conservai sempre em vós esse espírito religioso que vos anima [...] Porque a religiáo, não somente é necessária para os indivíduos e para as famílias, mas também para a sociedade. A história aí está para demonstrá-lo, a primeira pedra de qualquer sociedade sempre foi um altar, e quando essa pedra foi derrubada, também a sociedade caiu em ruína. Repito-vos, conservai sempre em

${ }^{19}$ CANDIDATO de Frei Damião. Diario de Pernambuco, Recife, 3 set. 1953. p. 3. 


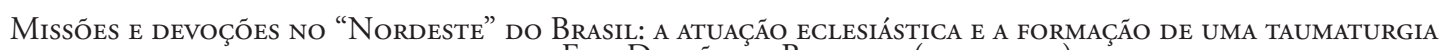
em torno do Frei Damiấo de Bozzano (I930-1940)

Carlos André Silva de Moura e Aerton Alexander de Carvalho Silva

vós este espírito de Jesus que vos anima e prestareis ao Brasil o maior serviço que lhes podeis prestar [...] Viva Nosso Senhor Jesus Cristo, viva Maria Imaculada, viva Sáo Francisco, viva o Papa, viva o clero, viva as autoridades civis e militares, viva o Nordeste, viva o Brasil. ${ }^{20}$

O discurso do frei assumia a defesa de uma categoria que estruturava as suas convicçóes. É possível notar o respeito à hierarquia, com citaçôes à trindade e a centralização eclesiástica representada pela imagem do Papa. Do mesmo modo, defendia as autoridades civis e militares, com a legitimação e a sacralização de um momento específico da história do Brasil. As ações do frei foram importantes para a desconstrução de um catolicismo comprometido com as questôes sociais, a crítica ao autoritarismo e a falta de liberdade, utilizado como modelo pelos militares entre os anos de 1964 e 1985. Os seus posicionamentos neste instante da história do Brasil estavam de acordo com o período de atuação entre as décadas de $1930 \mathrm{e}$ 1940, com a defesa das estruturas políticas hierárquicas do Nordeste do país.

Mesmo com as dificuldades de comunicação e deslocamento nos anos 1930, nos mais longínquos lugares por onde percorreu, as missóes do frei prosseguiram à margem das resoluçôes legislativas do final do século XIX e dos acordos diplomáticos entre a Igreja e o Estado. As suas açôes continuavam atribuindo sacralidade às autoridades civis, em gestos de aproximação e apropriação pública que cristalizavam a ideia de que, ali, estavam homens que deviam ser obedecidos e seguidos.

A luta contra os "inimigos", como a modernidade, o espiritismo e o protestantismo permanecia vigente como justificativa dos "bons costumes". A partir das representações elaboradas em torno do Frei Damião, desde o início das suas atividades religiosas no Brasil, com a construção da "fama de santidade", as narrativas sobre os seus feitos miraculosos, baseadas nas açôes desenvolvidas durante as missôes, ratificaram o fato de hoje o eclesiástico passar por um processo de reconhecimento oficial, como taumaturgo, pela Igreja Católica. As suas açôes colaboraram para a elaboração de discursos que o classificava como "[...] o maior Missionário que palmilha os sertóes no Nordeste brasileiro. Ouvindo-se as suas prédicas [...] temos a impressão que estamos diante de um Santo". ${ }^{21}$ A tramitação do processo de canonização do italiano referenda uma construção sociocultural historicamente legitimada pelos fiéis, a partir da formação de práticas fundamentais para a Igreja Católica durante o século XX.

Nesse sentido, é interessante compreender como os espaços geográficos, que também podem ser entendidos como lugares devocionais, foram fundamentais para a formação das narrativas em torno do Frei Damiáo. Os personagens e lugares das missóes colaboraram com as diferentes formas de leituras das propostas do religioso, atribuíram sentido às devoçóes,

\footnotetext{
${ }^{20}$ BOZZANO, Frei Damião. Agradecimento e bênção. Título de cidadão pernambucano, 27 de setembro de 1977. Arquivo mp3 (2'39”).

${ }^{21}$ FIGUEIREDO, Henrique. Postais da capital do Agreste "Frei Damiáo". Diario de Pernambuco, Recife, 18 dez. 1951.p. 9.
} 


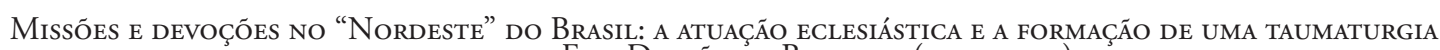
em torno do Frei Damiấo de Bozzano (I930-I940)

Carlos André Silva de Moura e Aerton Alexander de Carvalho Silva

com a elaboração das representaçôes de santidade ao frade, mesmo antes do reconhecimento das instituições oficiais.

\section{Fontes primárias}

A Ordem. Natal, Ano V, n. 11.610, ago. 1939.

BARRETO, Adalberto. Os santos nunca morrem. O Povo, Fortaleza, 2 jun. 1997.

BOZZANO, Frei Damião. Agradecimento e bênção. Título de cidadão pernambucano, $27 \mathrm{de}$ setembro de 1977. Arquivo mp3 (2'39").

BOZZANO, Frei Damião. Em defesa da fé. Recife: Edições Paulinas, 1955.

BRASIL. Presidência da República. Decreto 119-A. Disponível em: https://www.planalto. gov.br/ccivil_03/decreto/1851-1899/d119-a.htm. Acesso em: 29 ago. 2013.

CANDIDATO de Frei Damião. Diario de Pernambuco, Recife, 3 set. 1953. p. 3.

CONSTITUIÇÓES da Ordem dos Frades Menores Capuchinhos e ordenaçôes dos capitulos gerais: com a regra e o testamento de Sáo Francisco. Porto Alegre: Estef, 2014.

DIRETORIA das Senhoras de Caridade. Diario de Pernambuco, Recife, 22 jul. 1933. p. 4.

FIGUEIREDO, Henrique. Postais da capital do Agreste "Frei Damiāo". Diario de Pernambuco, Recife, 18 dez. 1951. p. 9.

FREI Damiáo pregando no morro do Redemptor em Cajazeiras. Diario de Pernambuco, Recife, 23 jul. 1939. p. 16.

LUCCA. Arquivo da Provincia dos Frades Capuchinhos. Cópia Pública III.

MARANHÃO, Gomes. O Sertão velho melhora de sorte. Resultado dumas santas missóes em Souza, na Parahyba. Diario de Pernambuco, Recife, 25 out. 1936. p. 14.

PIO IX. Encíclica Quanta Cura e Syllabus. 1864. Disponível em: www.filosofia.org/mfa/ far864a.htm. Acesso em: 4 set. 2019.

QUEIROZ, Octacilio Nobrega de. Reaviva-se o mysticismo das populaçôes do interior do nordeste. Diario de Pernambuco, Recife, 17 jan. 1941. p. 9.

REVISTA mensal dos PP. Capuchinhos da Penha e da Causa de D. Vital. Recife: Escola Gráfica Editora, ano VI, set./out., 1942.

\section{Referências}

AGUIAR, Sylvana Maria Brandão de; SILVA, Leda Cristina Correia da. Frei Damião: 


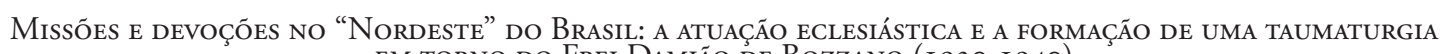
em torno do Frei Damiấ de Bozzano (I930-1940)

Carlos André Silva de Moura e Aerton Alexander de Carvalho Silva

trajetórias de vida, missóes, carisma e poderes. Paralellus, Recife, v. 6, n. 13, p. 445-466, jul./dez. 2015. Disponível em: http://www.unicap.br/ojs/index.php/paralellus/article/ view/659/611. Acesso em: 1 jun. 2020.

ALBUQUERQUE JUNIOR, Durval Muniz. A invenção do Nordeste: e outras artes. Recife; São Paulo: Massangana: Cortez, 1999.

ARANTES, José Tadeu. A trajetória do pensamento católico no Brasil. Agência FAPESP. Disponível em: http://agencia.fapesp.br/a_trajetoria_do_pensamento_catolico_no_ brasil/22616/. Acesso em: 20 abr. 2017.

ATKIN, Nicholas; TALLETT, Frank. Priests, Prelates and People: A History of European Catholicism since 1750. I.B. Tauris: London / New York, 2003.

AUBERT, Roger et al. The Church in the Industrial Age. New York: Crossroad, 1981.

AZZI, Riolando; GRIJP, Klaus Van der. História da Igreja no Brasil: ensaios de interpretação a partir do povo. Terceira época: 1930-1964. Petrópolis: Vozes, 2008. Tomo II/3-2:

BEOZZO, José Oscar et al. História da Igreja no Brasil - Ensaio de interpretação a partir do povo - Século XIX. Petrópolis: Vozes, 2008.

BLOCH, Marc Leopold Benjamin. Os reis taumaturgos: o caráter sobrenatural do poder régio França e Inglaterra. São Paulo: Companhia das Letras, 1999.

CAES, André Luiz. As portas do inferno não prevalecerão: a espiritualidade católica como estratégia política. Tese (Doutorado em História). Programa de Pós-Graduaçáo em História, Universidade Estadual de Campinas, Campinas, 2002.

CELANO, Frei Tomás. Primeira vida: vida de São Francisco de Assis escrita em 1228 D.C. São Paulo: Editora Família Católica, 2018

CHARTIER, Roger. À beira da falésia: a história entre incertezas e inquietude. Porto Alegre: UFRGS, 2002.

CHARTIER, Roger. A história cultural: entre práticas e representaçôes. Lisboa: DIFEL, 1990.

ESQUIVEL, Juan. Igreja Católica e Estado na Argentina e no Brasil. São Paulo: USP, 2003.

FROHLICH, Roland. Curso básico de História da Igreja. São Paulo: Paulus, 1987.

GOMES, Jociel. Frei Damiāo, Apóstolo do Nordeste. Recife: Causa de Beatificação e Canonização de Frei Damião, 2013.

HELGEN, Erika. Religious Conflict in Brazil: Protestants, Catholics, and the Rise of Religious Pluralism in Brazil in the Early Twentieth Century. New Haven and London: Yale University Press, 2020.

HOORNAERT, Eduardo. In memoriam Frei Damião. Revista Eclesiástica Brasileira, Petrópolis, v. 57, p. 670-674, 1997. 


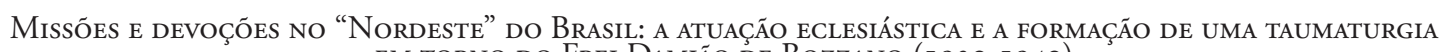
em torno do Frei Damiấ de Bozzano (I930-1940)

Carlos André Silva de Moura e Aerton Alexander de Carvalho Silva

KUNG, Hans. A Igreja Católica. Rio de Janeiro: Objetiva, 2002.

LAZZARI, Gianfranco (Ofmcap.). Padre Damiano di Bozzano. Apostolo della riconciliazione e maestro di vita spirituale. Il "Padre Pio del Brasile" S. Giovani Rotondo: Edizioni Frati Cappuccini, 2003.

MONTERO, Paulo. Deus na aldeia: missionários, índios e mediação cultural. São Paulo: Globo, 2006.

MOREIRA, Harley Abrantes. Onde há desespero, a esperança é importante?: uma história da expansão do cristianismo batista em Moçambique (1950-1992). Tese (Doutorado em História) - Programa de Pós-Graduaçáo em História, Universidade Estadual de Campinas, Campinas, 2020.

MOURA, Abdalaziz de. Frei Damiāo e os impasses da religiāo popular. Petrópolis: Vozes, 1978.

MOURA, Carlos André Silva de Moura. Concílio Plenário Latino-Americano, que entre os seus objetivos, buscou oferecer um novo impulso para a Igreja latino-americana. In: MOURA, Carlos André Silva de; MARROQUIM, Dirceu; HELGEN, Erika. (orgs.). Histórias transnacionais: intelectuais, devoçóes e ordens católicas na América Latina durante o século XX. Rio de Janeiro: Autografia, 2020.

MOURA, Carlos André Silva de Moura. Histórias cruzadas: intelectuais no Brasil e em Portugal durante a Restauração Católica (1910-1942). Lisboa: Imprensa de Ciências Sociais, 2018.

MOURA, Carlos André Silva de. Religião e educação: os projetos dos jesuítas portugueses em tempos de exílio no Brasil (1910-1938). Pró-posiçôes, Campinas, v. 30, p. 1-25, 2019. Disponível em: https://www.scielo.br/scielo.php?pid=S010373072019000100522\&script= sci_arttext. Acesso em: 25 mai. 2020.

MOURA, Carlos André Silva de; SILVA, Eliane Moura da; MOREIRA, Harley Abrantes (orgs.). Missóes, religião e cultura: estudos de história entre os séculos XVIII e XX. Curitiba: Prismas, 2017.

OLIVEIRA, Gildson. Frei Damiāo. O santo das missóes. São Paulo: FTD, 1997.

OOSTERHOUT, Maria da Conceição Mariano Cardoso Van. A cura pela fé: crenças, saberes e poderes no mundo rural do Nordeste brasileiro. Tese (Doutorado em Sociologia) - Programa de Pós-Graduação em Sociologia, Universidade Federal de Pernambuco, Recife, 2010.

POMPA, Maria Cristina. Religião como tradução: missionários, Tupi e Tapuia no Brasil colonial. São Paulo: EDUSC, 2003.

SERBIN, Keneth. Needs of the Heart. Notre Dame: University of Notre Dame Press, 2006. SILVA, Lêda Cristina Correia da. Prática e representaçôes hagiológicas: a devoção a Frei Damião 


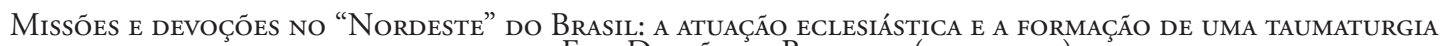
em torno do Frei Damiấo de Bozzano (I930-I940)

Carlos André Silva de Moura e Aerton Alexander de Carvalho Silva

de Bozzano (1931-2008). Tese (Doutorado em História) - Programa de Pós-Graduação em História, Universidade Federal de Pernambuco, Recife, 2009.

SILVA, Paulo Julião da. Entre a evangelização e a politica: a expansão missionária batista para o Brasil Central (1925-1939). Tese (Doutorado em História) - Programa de Pós-Graduação em História, Universidade Estadual de Campinas, Campinas, 2016.

ZAGONEL, Carlos Albino (org.). Capuchinhos no Brasil. Porto Alegre: Conferência dos Capuchinhos do Brasil, 2001. 